Article

\title{
Identification of a Novel O-Conotoxin Reveals an Unusual and Potent Inhibitor of the Human $\alpha 9 \alpha 10$ Nicotinic Acetylcholine Receptor
}

\author{
Shantong Jiang ${ }^{1}$, Han-Shen Tae ${ }^{2}$, Shaoqiong $\mathrm{Xu}^{1}{ }^{1}$, Xiaoxia Shao ${ }^{1}$, David J. Adams ${ }^{2, *}$ and \\ Chunguang Wang ${ }^{1, *}$ \\ 1 Department of Central Laboratory, Shanghai 10th People's Hospital, School of Life Sciences and Technology, \\ Tongji University, Shanghai 200092, China; jajst2010@163.com (S.J.); xsq1201@163.com (S.X.); \\ shxx@tongji.edu.cn (X.S.) \\ 2 Illawarra Health and Medical Research Institute (IHMRI), University of Wollongong, Wollongong, \\ NSW 2522, Australia; hstae@uow.edu.au \\ * Correspondence: djadams@uow.edu.au (D.J.A.); chunguangwang@tongji.edu.cn (C.W.); \\ Tel.: +61-2-4239-2264 (D.J.A.); +86-21-6598 4347 (C.W.)
}

Academic Editor: Keith B. Glaser

Received: 5 April 2017; Accepted: 6 June 2017; Published: 9 June 2017

\begin{abstract}
Conotoxins are a pool of disulfide-rich peptide neurotoxins produced by cone snails for predation and defense. They are a rich reservoir of novel ligands for ion channels, neurotransmitter receptors and transporters in the nervous system. In this study, we identified a novel conotoxin component, O-conotoxin GeXXVIIA, from the venom of Conus generalis. The native form of this component is a disulfide-linked homodimer of a 5-Cys-containing peptide. Surprisingly, our electrophysiological studies showed that, in comparison to the folded monomers, the linear peptide of this toxin had the highest inhibitory activity at the human $\alpha 9 \alpha 10$ nicotinic acetylcholine receptor (nAChR), with an $\mathrm{IC}_{50}$ of $16.2 \pm 1.4 \mathrm{nM}$. The activities of the N-terminal and C-terminal halves of the linear toxin are markedly reduced compared with the full-length toxin, suggesting that the intact sequence is required to potently inhibit the h $\alpha 9 \alpha 10 \mathrm{nAChR} . \alpha 9 \alpha 10 \mathrm{nAChRs}$ are expressed not only in the nervous system, but also in a variety of non-neuronal cells, such as cochlear hair cells, keratinocytes, epithelial and immune cells. A potent inhibitor of human $\alpha 9 \alpha 10 \mathrm{nAChRs}$, such as GeXXVIIA, would facilitate unraveling the functions of this nAChR subtype. Furthermore, this unusual nAChR inhibitor may lead to the development of novel $\alpha 9 \alpha 10 \mathrm{nAChR}$-targeting drugs.
\end{abstract}

Keywords: conotoxin; O-superfamily; nicotinic receptor; $\alpha 9 \alpha 10$; linear peptide

\section{Introduction}

The predatory cone snails (genus Conus) use their venoms as a weapon for predation and defense [1]. Based on their prey, cone snails are classified into fish-, mollusk-, or worm-hunting species, implying that their predation venoms may be largely different. Under the defensive evolutionary pressure, all cone snails have also developed defensive venoms against predators [2,3]. No matter what the purpose is, their venoms are primarily composed of an array of disulfide-rich peptides (conotoxins) that target membrane ion channels and neurotransmitter receptors in the nervous system [4]. As the number of conotoxin components is estimated to be in excess of 200,000, they are considered as a reservoir for novel drug leads for neuroscience research and disease treatment [5-7]. For example, $\omega$-conotoxin MVIIA isolated from C. magus acts as a selective $\mathrm{N}$-type $\mathrm{Ca}^{2+}$ channel inhibitor and has been developed as an analgesic drug commercially known as Ziconotide or Prialt [8-10]. 
Conotoxins are produced initially as gene-encoded polypeptide precursors and then maturated through proteolytic cleavages, and often post-translational modifications. Based on the signal peptide sequences of conotoxin precursors, the highly variable conotoxins are grouped into different superfamilies [11]. However, conotoxins belonging to the same superfamily do not necessarily have the same cysteine framework or functional target. One remarkable example is the O-superfamily conotoxins that include $\mathrm{Ca}^{2+}$ channel-inhibiting $\omega$-conotoxins, $\mathrm{K}^{+}$channel-inhibiting $\mathrm{k}$-conotoxins, $\mathrm{Na}^{+}$channel-modifying $\delta$-conotoxins, and $\mathrm{Na}^{+}$channel-inhibiting $\mu \mathrm{O}$-conotoxins [12].

Nicotinic acetylcholine receptors (nAChRs) are key in transmitting signals in the central and peripheral nervous systems, opening a cation-selective pore upon the binding of acetylcholine (ACh) to the extracellular domain [13]. nAChRs exist as homo- or hetero-pentameric channels and 17 subunits have been recognized in vertebrate species $(\alpha 1-\alpha 10, \beta 1-\beta 4, \gamma, \delta$, and $\varepsilon$ ). The skeletal muscle $n A C h R$ subtype is composed of $\alpha 1, \beta 1, \delta$, and $\varepsilon$ (adult isoform) or $\gamma$ (fetal isoform) subunits at 2:1:1:1 ratio. In contrast, neuronal nAChR subtypes are composed of only $\alpha$ and $\beta$ subunits except for $\alpha 7, \alpha 9$, and $\alpha 10$ subunits, which can form functional receptors without the participation of $\beta$ subunits. Each $n A C h R$ subtype has distinct tissue expression, pharmacological properties and physiological functions [14].

Although the heteromeric $\alpha 9 \alpha 10 \mathrm{nAChR}$ is generally characterized as neuronal, it is also expressed in non-neuronal cells such as cochlear hair cells, keratinocytes, pituitary pars tuberalis, epithelial and immune cells $[15,16]$. Investigation of the physiological roles of the $\alpha 9 \alpha 10$ subtype would be greatly facilitated by potent inhibitors of the human (h) $\alpha 9 \alpha 10 \mathrm{nAChR}$. In this study, we identified a novel 5 Cys-containing conotoxin from the venom of Conus generalis. The precursor sequence of this toxin demonstrated that it is a member of the O1-superfamily. Although the native form of this toxin is a disulfide-linked homodimer, surprisingly the linear peptide of this toxin is a potent inhibitor of $h \alpha 9 \alpha 10$ $\mathrm{nAChR}$, with an $\mathrm{IC}_{50}$ of $16.2 \pm 1.4 \mathrm{nM}$. This novel $\mathrm{nAChR}$ inhibitor may lead to the development of novel $\alpha 9 \alpha 10$ nAChR-targeting drugs.

\section{Results}

\subsection{Purification and Identification of a Five-Cys-Containing Component from the Venom of Conus generalis}

The separation of the $C$. generalis crude venom on a C18 semi-preparative reverse-phase HPLC column gave a series of peaks (Figure 1a). One minor peak, apart from two major peaks that have been studied previously $[17,18]$, was focused in this study. A secondary separation using a C18 analytical column (Figure 1b) revealed that there are three components in this minor peak, with the second having a molecular mass of $9695 \mathrm{Da}$. Interestingly, reduction of this component with dithiothreitol (DTT) changed its molecular mass to 4853 Da (Figure 1c), indicating that this component is also a disulfide-linked homodimer, similar to $\alpha \mathrm{D}$-GeXXA [18]. Subsequently, alkylation with N-ethylmaleimide (NEM) of the reduced monomeric peptide increased the molecular mass to $5479 \mathrm{Da}$, which confirmed the presence of five Cys residues in this polypeptide chain (Figure 1d). The odd number of Cys residues is unique for conotoxins, which prompted us to investigate further. 

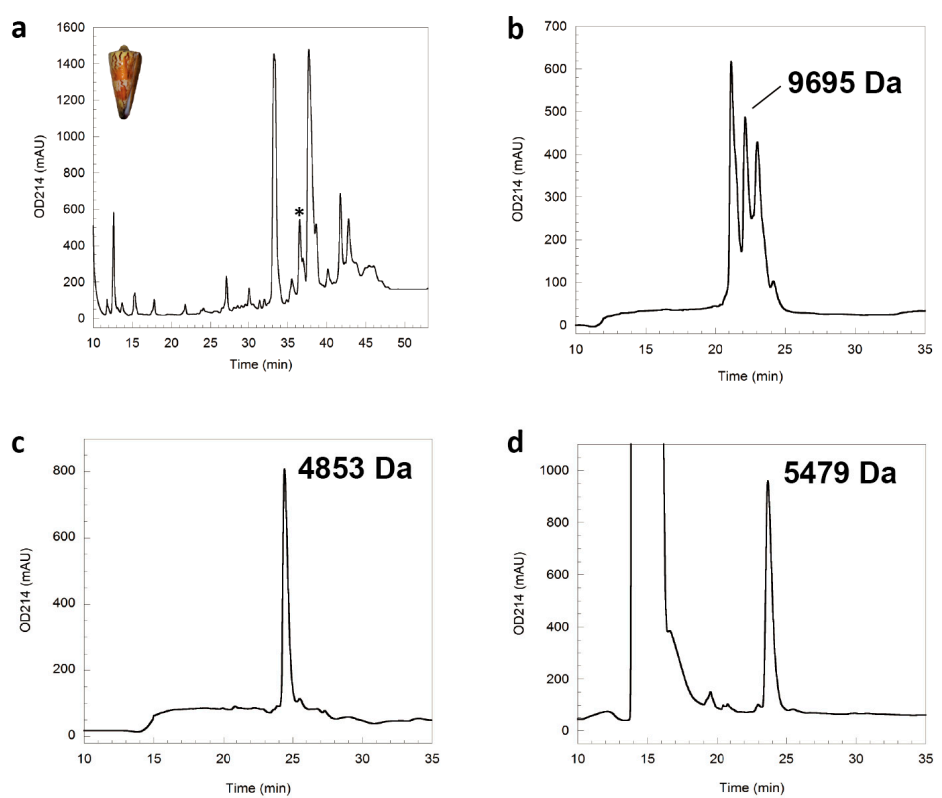

Figure 1. Purification and identification of O-conotoxin GeXXVIIA from Conus generalis. (a) Purification of crude venom extracted from $C$. generalis (shown in inset) on a ZORBAX C18 semi-preparative column. The asterisk indicates the fraction containing GeXXVIIA. The elution gradient is $0-50 \%$ Buffer B for 0-50 min with a flow rate of $0.5 \mathrm{~mL} / \mathrm{min}$. (b) Analytical scale purification of the GeXXVIIA-containing fraction from panel (a) on a C18 reverse-phase analytical column. The peak with a molecular mass of $9695 \mathrm{Da}$ is that of GeXXVIIA. The elution gradient is 10-30\% Buffer B for 0-10 min and 30-39\% Buffer B for 10-37 min with a flow rate of $0.5 \mathrm{~mL} / \mathrm{min}$. (c) Purification of the reduced GeXXVIIA after being treated with DTT on a C18 reverse-phase analytical column. The elution gradient is $10-45 \%$ Buffer B for 0-35 min with a flow rate of $0.5 \mathrm{~mL} / \mathrm{min}$. (d) Purification of the GeXXVIIA peptide after being alkylated with NEM on a C18 reverse-phase analytical column. The elution gradient is the same as that of panel (c).

\subsection{Sequence Determination and cDNA Cloning}

The reduced and alkylated monomeric peptide was first applied to Edman sequencing, which gave a partial N-terminal sequence of ALMSTGTNYRLP(T/K)(T/K)CRxSG, where $x$ is an unidentified residue. Then, gene specific primers were designed, based on this N-terminal sequence, and 3'-RACE was carried out to obtain the 3'-partial cDNA sequence. The amino acid sequence deduced from the 3'-partial cDNA sequence was highly homologous to the sequence of O1-superfamily conotoxin Mik41 [19]. Therefore, we took advantage of the known cDNA sequence of Mik41 and designed an upstream primer to amplify the 5 '-partial cDNA sequence of this toxin.

The complete cDNA sequence of this toxin was obtained by overlapping the 3'-partial and 5'-partial cDNA sequences (Figure 2a). The cDNA-encoded precursor has a typical conotoxin organization of 22-residue signal peptide, 11-residue pro-peptide, and 41-residue mature toxin. The conserved signal peptide clearly indicates that this toxin belongs to the O1-superfamily. Additionally, the precursor sequence of this toxin is similar to two other O1-superfamily conotoxins, Mik41 and GeXIVA (Figure 2b) $[19,20]$. However, the new toxin has an additional 13 amino acid residues at the N-terminus of the mature peptide and 5 Cys residues compared to 6 for MiK41 and 4 for GeXIVA.

The cysteine framework of this conotoxin is different from other conotoxins that often contain even numbers of Cys residues. Therefore, we numbered this framework as XXVII and named this toxin GeXXVIIA. The molecular mass of the cDNA-deduced mature toxin, $4809.6 \mathrm{Da}$, is slightly different from the mass of the reduced natural toxin, which is likely due to sequence polymorphism or post-translational modifications. 
a

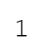

13

28

43

58

73

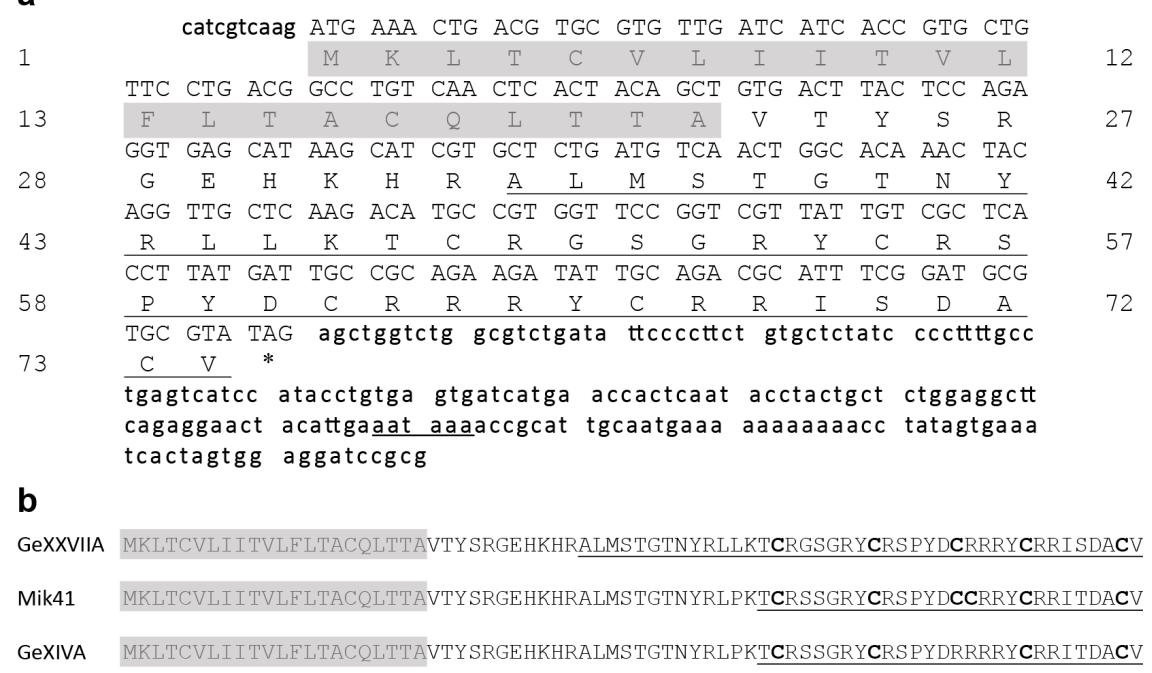

Figure 2. cDNA sequence of O-GeXXVIIA. (a) The cDNA sequence of GeXXVIIA and the cDNA-encoded precursor sequence. The coding region of cDNA is shown in capital letters. The signal peptide sequence is shadowed, and the mature peptide sequence is underlined. Between the signal sequence and mature toxin region is the pro-peptide region. ${ }^{*}$ represents the stop codon. (b) Alignment of the precursor sequences of GeXXVIIA, Mik41 [19], and GeXIVA [20]. Mature toxin sequences are underlined with the Cys residues highlighted in bold.

\subsection{Oxidative Refolding of GeXXVIIA}

The unique sequence of GeXXVIIA motivated us to investigate its biological activity. Due to the low amount of the native GeXXVIIA, we sought to chemically synthesize the linear peptide of GeXXVIIA and then refold it in vitro. However, the regular air oxidation and glutathione oxidation conditions failed to produce a peak with the expected molecular mass. We managed to have two disulfide bonds formed in each peptide only in the condition of $400 \mathrm{mM}$ arginine, with DTT and oxidized DTT as reducing-oxidizing pair reagents, and four different isomers with the same molecular mass were formed (Figure 3a). No dimeric product was observed, probably because the formation of the inter- and intra-chain disulfide bonds would require different oxidizing potential.
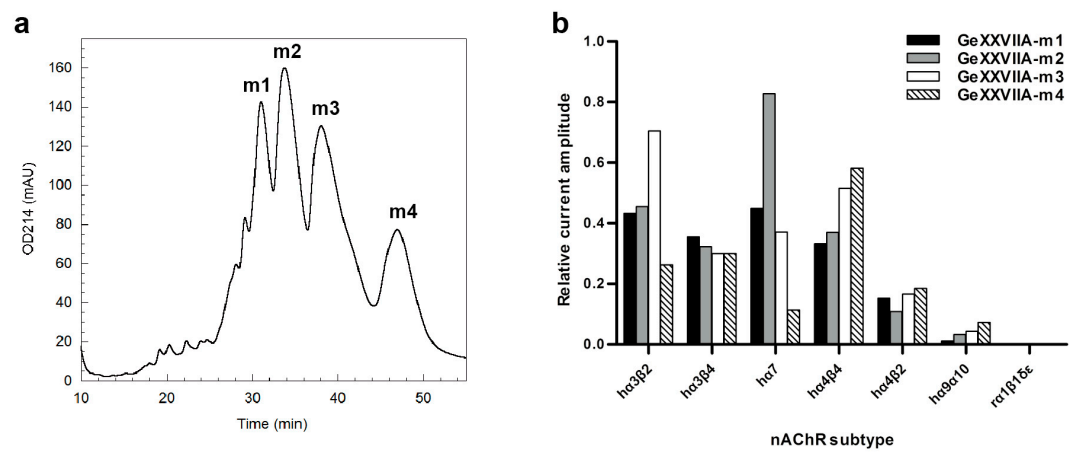

Figure 3. Preparation and $\mathrm{nAChR}$-inhibitory activities of the monomeric isomers of GeXXVIIA. (a) Separation of four GeXXVIIA monomeric isomers (m1, m2, $\mathrm{m} 3$, and $\mathrm{m} 4$ ) refolded in vitro on a C18 reverse-phase analytical column. The elution is isocratic at $22 \%$ Buffer B with a flow rate of $0.5 \mathrm{~mL} / \mathrm{min}$. The molecular masses of these four isomers are the same, $4807 \mathrm{Da}$, indicating that two disulfide bonds are formed in each isomer. (b) The inhibition of $5 \mu \mathrm{M}$ GeXXVIIA-m1, -m2, -m3, and - $\mathrm{m} 4$ on ACh-evoked peak current amplitude mediated by h $\alpha 3 \beta 2, \mathrm{~h} \alpha 3 \beta 4, \mathrm{~h} \alpha 7, \mathrm{~h} \alpha 4 \beta 4, \mathrm{~h} \alpha 4 \beta 2, \mathrm{~h} \alpha 9 \alpha 10$, and rodent (r) $\alpha 1 \beta 1 \varepsilon \delta \mathrm{nAChRs}$ ( $n=1$ oocyte for each $\mathrm{nAChR}$ subtype). 


\subsection{Inhibitory Effects of GeXXVIIA Monomeric Isomers on $n A C h R s$}

It has been reported previously that GeXIVA, which has similar sequence to the C-terminal sequence of GeXXVIIA, inhibits ACh-evoked current of nAChRs in a structure-insensitive manner [20]. Therefore, we tested the four monomeric isomers of GeXXVIIA (GeXXVIIA-m1 to -m4) at various $\mathrm{nAChR}$ subtypes heterologously expressed in Xenopus laevis oocytes, initially at $5 \mu \mathrm{M}$. Surprisingly, all GeXXVIIA isomers inhibited nAChR-mediated currents. Although the inhibition at h $\alpha 3 \beta 2, \alpha 3 \beta 4, \alpha 7$, and $\alpha 4 \beta 4 \mathrm{nAChR}$ subtypes was modest, these monomers all potently inhibited rodent $(\mathrm{r}) \alpha 1 \beta 1 \varepsilon \delta$ and h $\alpha 9 \alpha 10 \mathrm{nAChR}$ subtypes (Figure $3 \mathrm{~b}$ ).

\subsection{Inhibition Activity of the Linear GeXXVIIA and Its Two Fragments}

The results above demonstrated that the inhibitory activity of GeXXVIIA on different nAChR subtypes was not greatly affected by the different disulfide linkages in these isomers, similar to that of GeXIVA [20]. We then prepared a disulfide-free linear peptide of GeXXVIIA by modifying the Cys residues with iodoacetamide (IAA) (Figure 4a, left panel), and tested its activity at the two preferred subtypes, $\mathrm{r} \alpha 1 \beta 1 \varepsilon \delta$ and $h \alpha 9 \alpha 10 \mathrm{nAChRs}$. Remarkably, the same concentration $(5 \mu \mathrm{M})$ of the linear GeXXVIIA (GeXXVIIA-L) retained potent inhibitory activity on the ACh-evoked currents of these two nAChR subtypes (Figure $4 \mathrm{~b}$ ), which further highlighted that the folding of the peptide is not required for the interaction with nAChRs. This result also raised the possibility that the binding of the linear GeXXVIIA peptide with nAChR is only dependent on the sequence of the peptide.

In order to narrow down the critical sequence of GeXXVIIA-L responsible for the nAChR-inhibitory activity, we took advantage of the presence of the only two Asp residues in this toxin, and digested the linear GeXXVIIA with Asp-N protease into GeXXVIIA-L-Nter and GeXXVIIA-L-Cter fragments (Figure 4a). At $5 \mu \mathrm{M}$, the GeXXVIIA-L-Nter fragment strongly inhibited both $\mathrm{r} \alpha 1 \beta 1 \varepsilon \delta$ and $h \alpha 9 \alpha 10$ nAChR subtypes (Figure 4c), whereas the GeXXVIIA-L-Cter inhibited more strongly the $h \alpha 9 \alpha 10 \mathrm{nAChR}(>90 \%$ inhibition) than the $\mathrm{r} \alpha 1 \beta 1 \varepsilon \delta$ subtype ( $30 \%$ inhibition) (Figure $4 \mathrm{~d}$ ). These results suggest that the N-terminal part of GeXXVIIA-L retains more nAChR inhibition activity than the C-terminal part, at this high concentration at least.
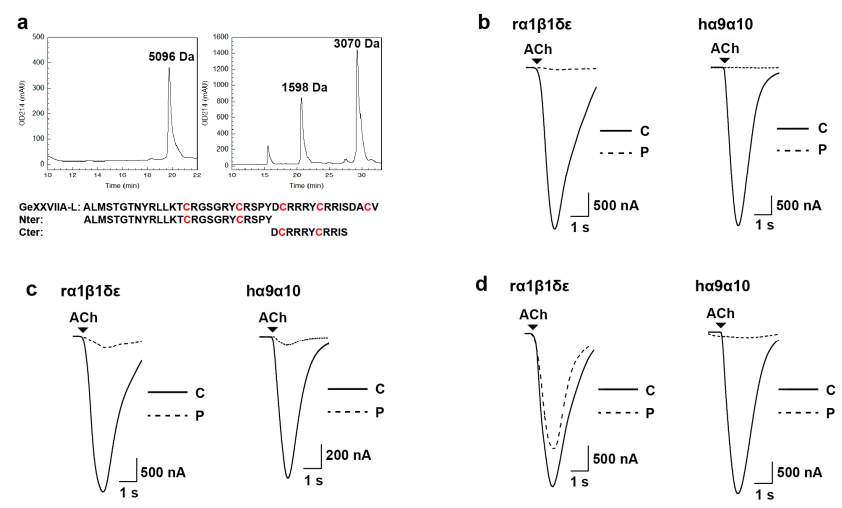

Figure 4. Preparation and nAChR-inhibitory activities of the linear GeXXVIIA and its N- and C-terminal fragments. (a) Left panel: Preparation of the linear peptide of GeXXVIIA (GeXXVIIA-L) alkylated with IAA on a C18 reverse-phase analytical column. Its molecular mass is $5096 \mathrm{Da}$. The elution gradient is $15-37 \%$ Buffer B for 0-22 min with a flow rate of $0.5 \mathrm{~mL} / \mathrm{min}$. Right panel: Two fragments were obtained after the digestion of GeXXVIIA-L by Asp-N protease. The elution gradient is 5-38\% acetonitrile for 0-33 min with a flow rate of $0.5 \mathrm{~mL} / \mathrm{min}$. The $\mathrm{N}$-terminal (Nter) and C-terminal (Cter) fragments of GeXXVIIA-L have a molecular mass of $3070 \mathrm{Da}$ and $1598 \mathrm{Da}$, respectively. Below are the sequences of GeXXVIIA-L, Nter and Cter peptides, with the IAA-blocked Cys residues shown in red. (b-d) Superimposed ACh-evoked currents mediated by $r \alpha 1 \beta 1 \varepsilon \delta$ and h $\alpha 9 \alpha 10$ nAChRs in the absence (C, control) and the presence of $5 \mu \mathrm{M}$ different GeXXVIIA peptides (P). Arrows ( $\mathbf{\nabla})$ indicate ACh application. The peptides are GeXXVIIA-L (b), GeXXVIIA-L-Nter (c), and GeXXVIIA-L-Cter (d). 


\subsection{IC $C_{50}$ Values of the GeXXVIIA-L and GeXXVIIA-L-Nter}

At $5 \mu \mathrm{M}$, GeXXVIIA-L, GeXXVIIA-L-Nter, and -Cter fragments inhibited h $\alpha 9 \alpha 10$ nAChR by $>90 \%$ (Figure $4 \mathrm{~b}-\mathrm{d}$ ), whereas at $300 \mathrm{nM}$, their inhibition levels diverged: the full-length linear GeXXVIIA still strongly inhibited h $\alpha 9 \alpha 10 \mathrm{nAChR}(>90 \%)$, but the two fragments produced only $~ 55 \%$ inhibition (Figure 5a). Interestingly, when the folded monomer GeXXVIIA-m1 was tested at $300 \mathrm{nM}$ as a reference, it gave a similar degree of inhibition as the two fragments of the linear peptide, but weaker than the full-length GeXXVIIA-L. Comparison between the inhibition levels of GeXXVIIA-m1 and GeXXVIIA-L implies that the disulfide linkage in the peptide decreased the inhibitory activity, on h $\alpha 9 \alpha 10 \mathrm{nAChR}$ at least.

To obtain the quantitative potencies of the linear GeXXVIIA and GeXXVIIA-L-Nter, we measured their $\mathrm{IC}_{50}$ values at $\mathrm{r} \alpha 1 \beta 1 \varepsilon \delta$ and $h \alpha 9 \alpha 10 \mathrm{nAChRs}$ (Figure $5 \mathrm{~b}$ ). At $\mathrm{r} \alpha 1 \beta 1 \varepsilon \delta \mathrm{nAChR}$, the full-length GeXXVIIA-L peptide gave an $\mathrm{IC}_{50}$ value of $774 \pm 48 \mathrm{nM}$, whereas the GeXXVIIA-L-Nter fragment had an $\mathrm{IC}_{50}$ of $2.19 \pm 0.24 \mu \mathrm{M}$, only about three-fold higher than GeXXVIIA-L, suggesting that the C-terminal part of the peptide does not contribute much to the interaction with this nAChR subtype. Unexpectedly, GeXXVIIA-L was highly potent at h $\alpha 9 \alpha 10 \mathrm{nAChR}$, with an $\mathrm{IC}_{50}$ of $16.2 \pm 1.4 \mathrm{nM}$. Moreover, the potency of GeXXVIIA-L-Nter at this subtype was 14-fold weaker, with an $\mathrm{IC}_{50}$ of $222.5 \pm 14.0 \mathrm{nM}$. The more dramatic difference between the full-length GeXXVIIA-L and GeXXVIIA-L-Nter suggests that the C-terminal part participates in the interaction with h $\alpha 9 \alpha 10$ nAChR more than with $r \alpha 1 \beta 1 \varepsilon \delta$ nAChR.

a

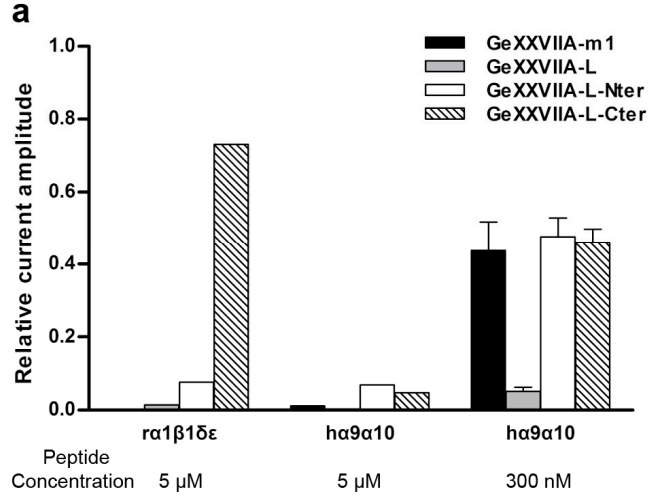

b

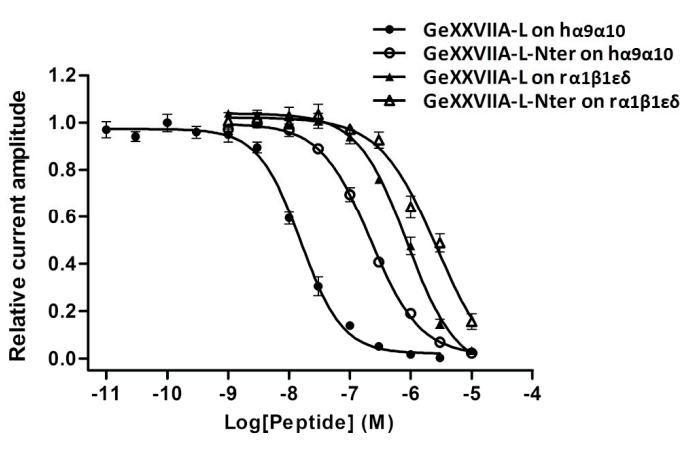

Figure 5. Antagonist potencies of GeXXVIIA-L and GeXXVIIA-L-Nter at the rodent $\alpha 1 \beta 1 \varepsilon \delta$ and human $\alpha 9 \alpha 10$ nAChRs. (a) Inhibition of ACh-evoked peak current amplitude mediated by $\mathrm{r} \alpha 1 \beta 1 \varepsilon \delta$ and h $\alpha 9 \alpha 10$ nAChRs by GeXXVIIA-m1, GeXXVIIA-L, GeXXVIIA-L-Nter, and GeXXVIIA-L-Cter at $5 \mu \mathrm{M}(n=1$ oocyte) and $300 \mathrm{nM}(n=3-7$ oocytes) peptide concentrations. Error bars indicate SEM. (b) Concentration-response curves obtained for GeXXVIIA-L and GeXXVIIA-L-Nter inhibition of $\mathrm{r} \alpha 1 \beta 1 \varepsilon \delta$ and $h \alpha 9 \alpha 10 \mathrm{nAChRs}$ expressed in Xenopus laevis oocytes. Full-length GeXXVIIA-L exhibits potent inhibitory activity at $\mathrm{h} \alpha 9 \alpha 10$ receptors with an $\mathrm{IC}_{50}$ of $16.2 \pm 1.4 \mathrm{nM}(n=4-8$ oocytes for each data point).

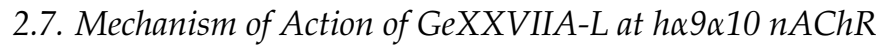

The high potency and the unique working conformation (linear peptide) of GeXXVIIA at h $\alpha 9 \alpha 10 \mathrm{nAChR}$ encouraged us to explore its mechanism of action. To ascertain whether it binds to the orthosteric ACh binding site, we determined GeXXVIIA-L inhibition (applied at IC $_{50}$ of $16.2 \mathrm{nM}$ ) of the h $\alpha 9 \alpha 10 \mathrm{nAChR}$-mediated currents evoked by different ACh concentrations. The ACh-evoked current amplitude was inhibited by $43.6 \pm 1.4 \%(n=10)$ when evoked with $6 \mu \mathrm{M}$ ACh, $46.9 \pm 2.4 \%(n=11)$ when evoked with $30 \mu \mathrm{M}$ ACh and $46.7 \pm 2.9 \%(n=9)$ when evoked with $100 \mu \mathrm{M}$ ACh. The insurmountable inhibition of $\mathrm{h} \alpha 9 \alpha 10 \mathrm{nAChR}$ by GeXXVIIA-L when raising the ACh concentration indicates that GeXXVIIA-L is a non-competitive antagonist at h $\alpha 9 \alpha 10 \mathrm{nAChR}$. Furthermore, GeXXVIIA-L (16.2 nM) inhibition of ACh-evoked currents at h $\alpha 9 \alpha 10 \mathrm{nAChR}$ was similar 
at all membrane potentials tested $(45.6 \pm 7.3 \%$ at $-120 \mathrm{mV}(n=5), 44.9 \pm 5.6 \%$ at $-80 \mathrm{mV}(n=9)$, and $45.6 \pm 8.1 \%$ at $-40 \mathrm{mV}(n=4))$. These results indicate that GeXXVIIA-L inhibition of h $\alpha 9 \alpha 10 \mathrm{nAChR}$ is voltage-independent, suggesting that the peptide does not enter the membrane electric field and is unlikely to be an open channel pore blocker.

\section{Discussion}

Conotoxins are well known for their structural and functional diversity. In this study, we identified a novel conotoxin GeXXVIIA from the South China Sea mollusk C. generalis and classified it as a member of the O1-superfamily conotoxins. However, the mature peptide sequence of GeXXVIIA contains five Cys residues, which is distinct from the cysteine framework VI/VII (C-C-CC-C-C) in most of the O-superfamily conotoxins [12]. Comparison with the cDNA sequence of Mik41 suggests that the cysteine framework of GeXXVIIA may well be the result of a point mutation that changes the codon of the fourth Cys (TGC) in Mik41 into a codon of Arg (CGC) in GeXXVIIA [19]. The random point mutation in conotoxin genes has been found to be one of the mechanisms for conotoxin diversity [21]. Due to this unique cysteine framework, we propose that GeXXVIIA represents a new branch of the O1-superfamily.

It is uncommon for conotoxins to have odd number of Cys residues, as conotoxins are often disulfide-linked monomers, whereas an uneven number of Cys residues suggests the existence of interchain disulfide bond. Other conotoxins containing an odd number of Cys residues include TxXIIIA (with five Cys residues in the short sequence TSDCCFYNCCC) and the con-ikot-ikot (with 13 Cys residues in the mature sequence) [22,23]. Both of them form disulfide-linked homodimers, as believed for the native GeXXVIIA. However, the elucidation of the dimerization linkage remains a challenge. So far, the linkage is known only for two dimeric conotoxins, con-ikot-ikot and $\alpha \mathrm{D}-\mathrm{GeXXA}$, by X-ray structure determination in both cases $[18,24]$. However, the very low abundance of the natural dimeric GeXXVIIA is a major obstacle for the structural study of this toxin.

Following the report of GeXIVA [20], we discovered that the monomeric GeXXVIIA has nAChR-inhibitory activity. Furthermore, different disulfide linkages were found not to change much the nAChR-inhibitory activity of GeXXVIIA (Figure 3), which is consistent with the properties of GeXIVA [20]. As the predicted sequence of GeXIVA differs from GeXXVIIA sequence mainly by the lack of N-terminal 13 residues, it appears that the basal nAChR-inhibitory activity of GeXXVIIA is mediated by the C-terminal part analogous to GeXIVA. However, quantitative comparison of the toxin activities suggests that the existence of the N-terminal extension in GeXXVIIA enhances the potency and specificity on $h \alpha 9 \alpha 10 \mathrm{nAChR}$.

The $\alpha 9 \alpha 10$ subtype nAChRs were originally characterized in cochlear hair cells where they function in mediating synaptic transmission between the olivocochlear system and auditory hair cells of the cochlea [25-27]. Other studies reported that $\alpha 9 \alpha 10 \mathrm{nAChRs}$ are expressed in different tissues, including dorsal root ganglia, skin, lymphocyte, sperm, and immune cells [28-32]. Potent $\alpha 9 \alpha 10$-specific antagonizing conotoxins, such as $\alpha$-RgIA, $\alpha$-Vc1.1 and the bead isomer of GeXIVA, have been shown to provide long lasting relief in rat models of neuropathic pain, although the underlying mechanism remains controversial [20,33-39]. Recent studies have also shown that the $\alpha 9$ subunit is over-expressed in breast tumors [40]. Therefore, considering the physiological importance of h $\alpha 9 \alpha 10$ $\mathrm{nAChR}$, ligands with high potency on this $\mathrm{nAChR}$ subtype would be of great potential. However, the development of h $\alpha 9 \alpha 10 \mathrm{nAChR}$-selective conotoxins is hindered by the fact that most of the $\alpha 9 \alpha 10$ subtype-specific conotoxins have only been studied on the rat nAChR subtype, examples including $\alpha$-RgIA, $\alpha$-Vc1.1, $\alpha$ S-GVIIIA, and $\alpha \mathrm{O}$-GeXIVA (Table 1). Prior to this study, only $\alpha$ D-GeXXA $\left(\mathrm{IC}_{50}=28 \mathrm{nM}\right)$ [18] and GeXIVA bead isomer $\left(\mathrm{IC}_{50}=20 \mathrm{nM}\right)$ [41] showed high potency at the $\mathrm{h} \alpha 9 \alpha 10$ subtype. The novel conotoxin GeXXVIIA identified in this study has a similarly high potency at the $\mathrm{h} \alpha 9 \alpha 10$ subtype $\left(\mathrm{IC}_{50}=16.2 \mathrm{nM}\right)$. However, unlike the conotoxins discussed above, in which their potency is dependent on the disulfide folding, GeXXVIIA is a more potent inhibitor as a linear peptide. This unique property not only facilitates the synthesis and use of this toxin, but 
also suggests that GeXXVIIA has an unusual nAChR-inhibition mechanism. Indeed, the comparable inhibition by GeXXVIIA-L tested with different ACh concentrations or at different membrane potentials demonstrates that GeXXVIIA-L is neither a competitive antagonist, nor a channel pore blocker of nAChR. Most likely, GeXXVIIA-L is a new class of nAChR allosteric inhibitor.

It is unusual among conotoxins that the linear GeXXVIIA is more potent than its folded counterparts (Figure 5a). This suggests that the interaction between GeXXVIIA and $\alpha 9 \alpha 10 \mathrm{nAChR}$ is improved with an extended peptide of GeXXVIIA, most likely because the nAChR-binding sites in GeXXVIIA are distributed along the sequence of this toxin. This is probably why both the two halves of GeXXVIIA have diminished nAChR-inhibitory activities compared to the full-length toxin. In other words, both the two halves of linear GeXXVIIA cooperatively contribute to the high potency of this toxin. Given the unusual high content of basic residues (nine Arg and one Lys out of 41 residues) in the GeXXVIIA sequence (Figure 2), it is highly likely that the electrostatic interaction with the nAChR acidic residues plays a major role in binding. Consistent with this proposal, a strongly electronegative surface was identified in the extracellular vestibule from the crystal structural study of $\alpha 4 \beta 2 \mathrm{nAChR}$ [42]. Identification of the binding site of GeXXVIIA on $\alpha 9 \alpha 10 \mathrm{nAChR}$ may furnish valuable information in understanding the gating mechanism of this receptor.

In summary, we have identified a novel O-superfamily conotoxin GeXXVIIA from the venom of $C$. generalis. We discovered that the linear peptide of GeXXVIIA can strongly inhibit the activity of the human $\alpha 9 \alpha 10 \mathrm{nAChR}$ with an $\mathrm{IC}_{50}$ of $16.2 \mathrm{nM}$. Although $\mathrm{nAChR}$ may not be the target of the native GeXXVIIA toxin that is a disulfide-linked homodimer, the high potency of its linear peptide on $\mathrm{h} \alpha 9 \alpha 10 \mathrm{nAChR}$ per se is of great interest. These findings suggest an unusual inhibition mechanism on $\mathrm{nAChR}$, which merits further investigation, both for the understanding of $\mathrm{nAChR}$ structure and function and for the development of novel nAChR inhibitors.

Table 1. Conotoxins with high potency on $\alpha 9 \alpha 10$ nAChRs.

\begin{tabular}{|c|c|c|c|c|c|c|}
\hline $\begin{array}{l}\text { Super- } \\
\text { Family }\end{array}$ & $\begin{array}{l}\text { Toxin } \\
\text { Name }\end{array}$ & Conus Species & Toxin Sequence & $\begin{array}{c}\text { Species of } \\
\alpha 9 \alpha 10 \mathrm{nAChR}\end{array}$ & $\mathrm{IC}_{50}(\mathrm{nM})$ & Reference \\
\hline $\mathrm{O}$ & GeXXVIIA & C. generalis & 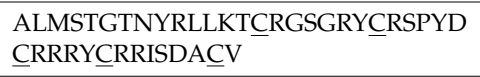 & H. sapiens & 16.2 & This study \\
\hline $\mathrm{O}$ & GeXIVA & C. generalis & TㅁRSSGRYㅁRSPYDRRRRY $\underline{C R R I T D A} \underline{C V}$ & $\begin{array}{l}\text { R. norvegicus } \\
\text { H. sapiens }\end{array}$ & $\begin{array}{c}4.6 \\
20.3\end{array}$ & $\begin{array}{l}{[20]} \\
{[41]}\end{array}$ \\
\hline A & RgIA & C. regius & GCCSDPRCRYRㅁ & $\begin{array}{l}\text { R. norvegicus } \\
\text { H. sapiens }\end{array}$ & $\begin{array}{l}1.5 \\
494\end{array}$ & [43] \\
\hline A & Vc1.1 & C. victoriae & GCCSDPRCNYDHPEIC $^{*}$ & R. norvegicus & 19 & [33] \\
\hline S & GVIIIB & C. geographus & 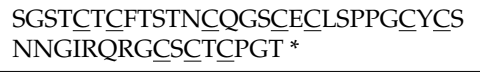 & R. norvegicus & 9.8 & [44] \\
\hline $\mathrm{D}$ & GeXXA & C. generalis & $\begin{array}{l}\text { DVHRP CQSVRPGRVWGKCCLTRLCST } \\
\text { MCCARADCTCVYHTWRGHGCSCVM }\end{array}$ & $\begin{array}{l}\text { R. norvegicus } \\
\text { H. sapiens }\end{array}$ & $\begin{array}{l}1.2 \\
28\end{array}$ & [12] \\
\hline
\end{tabular}

\section{Materials and Methods}

\subsection{Toxin Isolation and Purification}

Specimens of C. generalis were collected from the South China Sea, near the coast of Sanya, Hainan Island, China. In order to extract the crude venom, the venom ducts were homogenized and suspended in $0.1 \%(v / v)$ trifuoroacetic acid (TFA). After centrifugation at $12,000 \times g$ at $4{ }^{\circ} \mathrm{C}$ for $15 \mathrm{~min}$, the supernatant was collected and the pellet was stirred in $0.1 \%$ TFA for $30 \mathrm{~min}$, then re-centrifuged. Precipitates were pooled and re-extracted successively with $0.1 \%$ TFA in 20, 30, 40 and 50\% acetonitrile. Supernatants were combined, lyophilized, and stored at $-20^{\circ} \mathrm{C}$.

To purify the conotoxins, the lyophilized crude venom was dissolved in Buffer A (0.1\% TFA). After centrifugation, the supernatant was applied on a ZORBAX C18 semi-preparative column $(9.4 \times 250 \mathrm{~mm}$, Agilent, Santa Clara, CA, USA) and eluted with a gradient of buffer B $(0.1 \%$ TFA 
in 100\% acetonitrile) using an Agilent 1100 HPLC system. Further purification was performed on a ZORBAX C18 analytical column $(4.6 \times 250 \mathrm{~mm}$, Agilent, Santa Clara, CA, USA).

\subsection{Toxin Characterization and N-Terminal Sequencing}

The purified conotoxin component was dissolved in the reduction buffer of $100 \mathrm{mM}$ Tris- $\mathrm{HCl}$, $\mathrm{pH} 8.7$ and $2 \mathrm{mM}$ EDTA, and reduced with a 100-fold excess of dithiothreitol (DTT) at $37^{\circ} \mathrm{C}$ for $1 \mathrm{~h}$. The reduced peptide was purified on a ZORBAX C18 analytical column $(4.6 \times 250 \mathrm{~mm}$, Agilent, Santa Clara, CA, USA). Thiol groups were alkylated with $10 \mathrm{mM} \mathrm{N}$-ethylmaleimide (NEM) in the reduction buffer at $37^{\circ} \mathrm{C}$ in the dark for $0.5 \mathrm{~h}$. The modified peptide was purified by a $\mathrm{C} 18$ reverse-phase column on HPLC, and directly used for N-terminal sequencing on ABI 491A Procise ${ }^{\circledR}$ Protein Sequencing System (Applied Biosystems, Foster City, CA, USA).

The mass spectrometry analyses of the native, reduced and S-alkylated toxins were performed on a Q-trap mass spectrometer (Applied Biosystems, Foster City, CA, USA), using the scan type of Enhanced MS. The apparatus was equipped with a TurboIonSpray source and operated in positive ionization mode.

\section{3. cDNA Cloning}

Total RNA was extracted from homogenized venom duct tissues using Trizol Reagent (Invitrogen, Carlsbad, CA, USA) according to the manufacturer's protocol. Reverse transcription was carried out using a universal oligo dT-containing adapter primer 5'-GGC CAC GCG TCG ACT AGT AC (dT) $17-3^{\prime}$ (Superscript II Kit, Invitrogen, Carlsbad, CA, USA). The resulting CDNA was used as a template for cDNA-cloning PCR.

Complete cDNA sequence of this toxin was obtained by overlapping the $3^{\prime}$ - and 5'-partial cDNA sequences. The 3'-partial cDNA was first amplified through two rounds of PCR. The first PCR reaction was carried out using a degenerate oligonucleotide primer GSP1 (5'-GCNYTRATGTCN ACNGGNACNAAYTAY-3', Y: T/C, R: G/A, N: A/T/G/C), designed based on the N-terminal sequence (ALMSTGTNY-) and an outer primer provided by the $3^{\prime}$-RACE kit (Takara, Dalian, China). The second round of PCR amplification was carried out using the product of the first round PCR as the template by pairing the upstream primer GSP2 (5'-ATGTCNACNGGNACNAAYTAY-3'), designed based on the partial N-terminal sequence (-MSTGTNY-) with an inner primer provided by the kit. The $\sim 250$ bp PCR products were ligated into pGEM-T Easy vector (Promega, Madison, WI, USA) for sequencing.

Sequence comparison of the 3'-partial cDNA obtained above with other conotoxins showed that the mature peptide sequence of this toxin displays a high degree of homology to that of O-superfamily conotoxin Mik41 [19]. As the signal peptide of the O-superfamily is highly conserved, an upstream primer SP1 (5'-CATCGTCAAGATGAAACTGACG-3') was designed based on the known cDNA sequence of Mik41. According to the 3'-partial sequence of GeXXVIIA, we designed a specific antisense primer GSP3 (5'-CACAGGTATGGATGACTCAGG'-3') corresponding to the 3'-untranslated region. The 5'-partial cDNA of GeXXVIIA was amplified from the total cDNAs of $C$. generalis with these two primers and ligated into pGEM-T Easy vector (Promega, Madison, WI, USA) for sequencing.

\subsection{Peptide Synthesis and Refolding}

The linear peptide of GeXXVIIA, with all 5 Cys residues unprotected, was synthesized by the Chinese Peptide Company (Hangzhou, China). Oxidative folding of the purified linear peptide $(20 \mu \mathrm{M})$ was performed at $4{ }^{\circ} \mathrm{C}$ for one week in a buffer comprising $50 \mathrm{mM}$ Tris- $\mathrm{HCl}, \mathrm{pH}$ 8.0, $400 \mathrm{mM}$ arginine, $0.02 \mathrm{mM}$ DTT, and $0.3 \mathrm{mM}$ oxidized DTT. The oxidized products were purified on a ZORBAX C18 HPLC analytical column $(4.6 \times 250 \mathrm{~mm}$, Agilent $)$ with isocratic elution. Each monomer component was applied to a secondary HPLC purification. 


\subsection{Peptide Alkylation and Digestion by Protease Asp-N}

The synthesized linear GeXXVIIA was alkylated with $10 \mathrm{mM}$ iodoacetamide (IAA) in $100 \mathrm{mM}$ Tris-HCl, pH 8.7, and $2 \mathrm{mM}$ EDTA at $22^{\circ} \mathrm{C}$ in the dark for $1 \mathrm{~h}$. The alkylated linear peptide GeXXVIIA-L was purified on a ZORBAX C18 HPLC analytical column $(4.6 \times 250 \mathrm{~mm}$, Agilent). The digestion of alkylated GeXXVIIA-L was carried out in $100 \mathrm{mM}$ Tris-HCl, pH 8.5, using $3 \mu \mathrm{g} / \mathrm{mL}$ Asp-N (Sigma, St Louis, MO, USA) at $37^{\circ} \mathrm{C}$ for $18 \mathrm{~h}$. The digested products were separated on a ZORBAX C18 HPLC analytical column $(4.6 \times 250 \mathrm{~mm}$, Agilent).

\subsection{Oocyte Two-Electrode-Voltage Clamp Recordings}

Oocyte preparation, RNA preparation, and expression of nAChR subunits in Xenopus oocytes were performed as described previously [12]. All procedures were approved by the University of Sydney Animal Ethics Committee. Plasmid constructs of rat $(\alpha 1, \beta 1$, and $\delta)$, mouse $(\varepsilon)$ and human $(\alpha 3, \alpha 4, \alpha 7, \alpha 9, \alpha 10, \beta 2$, and $\beta 4)$ nAChR subunits were linearized for in vitro mRNA synthesis using mMessage mMachine transcription kit (AMBION, Forster City, CA, USA).

Stage V-VI Xenopus laevis oocytes were defolliculated with collagenase (Worthington Biochemical Corp., Lakewood, NJ, USA) at room temperature $\left(20-25^{\circ} \mathrm{C}\right)$ for $1 \mathrm{~h}$ in OR-2 solution containing (in $\mathrm{mM}$ ) $82.5 \mathrm{NaCl}, 2 \mathrm{KCl}, 1 \mathrm{MgCl}_{2}$, and $5 \mathrm{HEPES}$ at $\mathrm{pH}$ 7.4. Oocytes were injected with $5 \mathrm{ng}$ cRNA for h $\alpha 3 \beta 2$, $\alpha 3 \beta 4, \alpha 4 \beta 2, \alpha 4 \beta 4, \alpha 7$ or rodent $\alpha 1 \beta 1 \delta \varepsilon$ nAChRs, and 35 ng cRNA for h $\alpha 9 \alpha 10$ nAChR (concentration confirmed spectrophotometrically and by gel electrophoresis) using glass pipettes. Oocytes were incubated at $18^{\circ} \mathrm{C}$ in sterile ND96 solution composed of (in $\mathrm{mM}$ ) $96 \mathrm{NaCl}, 2 \mathrm{KCl}, 1 \mathrm{CaCl}_{2}, 1 \mathrm{MgCl}_{2}$, and 5 HEPES at $\mathrm{pH} 7.4$, supplemented with $5 \%$ fetal bovine serum, $50 \mathrm{mg} / \mathrm{L}$ gentamicin (GIBCO, Grand Island, NY, USA) and 10,000 U/mL penicillin-streptomycin (GIBCO, Grand Island, NY, USA).

Membrane currents were recorded from oocytes expressing nAChRs at room temperature, using a GeneClamp 500B amplifier and pClamp9 software interface (Molecular Devices, Sunnyvale, CA, USA) in a two-electrode voltage-clamp recording configuration (holding potential $-80 \mathrm{mV}$ ). In a series of experiments, the effect of different membrane potentials $(-120,-80$, and $-40 \mathrm{mV})$ on GeXXVIIA inhibition of h $\alpha 9 \alpha 10 \mathrm{nAChRs}$ was tested. Voltage-recording and current-injecting microelectrodes were pulled from GC150T-7.5 borosilicate glass (Harvard Apparatus Ltd., Holliston, MA, USA), giving tip resistances of $0.3-1.5 \mathrm{M} \Omega$ when filled with $3 \mathrm{M} \mathrm{KCl}$. Oocytes were perfused with ND96 solution at a rate of $2 \mathrm{~mL} / \mathrm{min}$. Oocytes expressing h $\alpha 9 \alpha 10 \mathrm{nAChRs}$ were incubated in $100 \mu \mathrm{M}$ BAPTA-AM $\sim 3 \mathrm{~h}$ before recording and perfused with ND115 solution containing (in $\mathrm{mM}$ ): $115 \mathrm{NaCl}, 2.5 \mathrm{KCl}, 1.8 \mathrm{CaCl}_{2}$, and 10 HEPES at $\mathrm{pH} 7.4$.

Initially, oocytes were briefly washed with bath solution (ND96/ND115) followed by three applications of acetylcholine $(\mathrm{ACh})$ at half-maximal effective concentration $\left(\mathrm{EC}_{50}\right)$ of $6 \mu \mathrm{M}$ for h $\alpha 3 \beta 2$, h $\alpha 9 \alpha 10$ and $h \alpha 4 \beta 4 \mathrm{nAChRs}, 300 \mu \mathrm{M}$ for h $\alpha 3 \beta 4,100 \mu \mathrm{M}$ for $\mathrm{h} \alpha 7,3 \mu \mathrm{M}$ for $\mathrm{h} \alpha 4 \beta 2$, and $1 \mu \mathrm{M}$ for $\mathrm{r} \alpha 1 \beta 1 \varepsilon \delta \mathrm{nAChRs}$. Washout with bath solution was done for 3 min between ACh applications. GeXXVIIA-L inhibition of h $\alpha 9 \alpha 10$ nAChRs was also examined at different ACh concentrations as indicated. Oocytes were incubated with peptides for $5 \mathrm{~min}$ with the perfusion system turned off, followed by co-application of ACh and peptide with flowing bath solution. All peptide solutions were prepared in ND96/ND115 + 0.1\% bovine serum albumin. Peak current amplitude evoked by ACh was measured before and following incubation with peptide in order to determine the effect on specific nAChR subtype. Concentration-dependent response curves for antagonists were fitted by unweighted nonlinear regression to the following logistic equation:

$$
\mathrm{E}_{\mathrm{x}}=\mathrm{E}_{\max } \mathrm{X}^{\mathrm{nH}} /\left(\mathrm{X}^{\mathrm{nH}}+\mathrm{IC}_{50}{ }^{\mathrm{nH}}\right),
$$

where $E_{X}$ is the response, $X$ is the antagonist concentration, $E_{\max }$ is the maximal response, $n^{\mathrm{H}}$ is the slope factor, and $\mathrm{IC}_{50}$ is the antagonist concentration giving half-maximal response. All electrophysiological data were pooled ( $n=4-11$ oocytes for each data point) and represented as means \pm standard error of the mean (SEM). The $\mathrm{IC}_{50}$ was determined from the concentration-response curve and reported with 
error of the fit. Computation was performed using GraphPad Prism 5 (GraphPad Software, La Jolla, CA, USA).

Acknowledgments: This work was supported by National Natural Science Foundation of China (grant nos. 31570771 and 31500626) and the Australian Research Council (ARC Discovery Grant DP150103990 to D.J.A.). The cDNA of GeXXVIIA was deposited into Genbank with an accession number KY523472.

Author Contributions: C.W. and D.J.A. designed and supervised the experiments; S.J., S.X., and X.S. performed the experiments of peptide characterization; H.-S.T. performed the experiments of electrophysiological activity; and C.W. and D.J.A. wrote the paper with input from all the authors.

Conflicts of Interest: The authors declare no conflict of interest.

\section{References}

1. Olivera, B.M. Conus Venom Peptides: Reflections from the biology of clades and species. Annu. Rev. Ecol. Syst. 2002, 33, 25-47. [CrossRef]

2. Dutertre, S.; Jin, A.H.; Vetter, I.; Hamilton, B.; Sunagar, K.; Lavergne, V.; Dutertre, V.; Fry, B.G.; Antunes, A.; Venter, D.J.; et al. Evolution of separate predation- and defence-evoked venoms in carnivorous cone snails. Nat. Commun. 2014, 5, 3521. [CrossRef] [PubMed]

3. Olivera, B.M.; Showers Corneli, P.; Watkins, M.; Fedosov, A. Biodiversity of cone snails and other venomous marine gastropods: Evolutionary success through neuropharmacology. Annu. Rev. Anim. Biosci. 2014, 2, 487-513. [CrossRef] [PubMed]

4. Terlau, H.; Olivera, B.M. Conus venoms: A rich source of novel ion channel-targeted peptides. Physiol. Rev. 2004, 84, 41-68. [CrossRef] [PubMed]

5. Lewis, R.J.; Dutertre, S.; Vetter, I.; Christie, M.J. Conus venom peptide pharmacology. Pharmacol. Rev. 2012, 64, 259-298. [CrossRef] [PubMed]

6. Essack, M.; Bajic, V.B.; Archer, J.A. Conotoxins that confer therapeutic possibilities. Mar. Drugs 2012, 10, 1244-1265. [CrossRef] [PubMed]

7. Mir, R.; Karim, S.; Kamal, M.A.; Wilson, C.M.; Mirza, Z. Conotoxins: Structure, therapeutic potential and pharmacological applications. Curr. Pharm. Des. 2016, 22, 582-589. [CrossRef] [PubMed]

8. Wermeling, D.P. Ziconotide, an intrathecally administered N-type calcium channel antagonist for the treatment of chronic pain. Pharmacotherapy 2005, 25, 1084-1094. [CrossRef] [PubMed]

9. Schmidtko, A.; Lotsch, J.; Freynhagen, R.; Geisslinger, G. Ziconotide for treatment of severe chronic pain. Lancet 2010, 375, 1569-1577. [CrossRef]

10. Webster, L.R. The relationship between the mechanisms of action and safety profiles of intrathecal morphine and Ziconotide: A review of the literature. Pain Med. 2015, 16, 1265-1277. [CrossRef] [PubMed]

11. Kaas, Q.; Yu, R.; Jin, A.H.; Dutertre, S.; Craik, D.J. ConoServer: Updated content, knowledge, and discovery tools in the conopeptide database. Nucleic Acids Res. 2012, 40, D325-D330. [CrossRef] [PubMed]

12. Heinemann, S.H.; Leipold, E. Conotoxins of the O-superfamily affecting voltage-gated sodium channels. Cell. Mol. Life Sci. 2007, 64, 1329-1340. [CrossRef] [PubMed]

13. Gotti, C.; Clementi, F. Neuronal nicotinic receptors: From structure to pathology. Prog. Neurobiol. 2004, 74, 363-396. [CrossRef] [PubMed]

14. Albuquerque, E.X.; Pereira, E.F.; Alkondon, M.; Rogers, S.W. Mammalian nicotinic acetylcholine receptors: From structure to function. Physiol. Rev. 2009, 89, 73-120. [CrossRef] [PubMed]

15. Del Bufalo, A.; Cesario, A.; Salinaro, G.; Fini, M.; Russo, P. $\alpha 9 \alpha 10$ nicotinic acetylcholine receptors as target for the treatment of chronic pain. Curr. Pharm. Des. 2014, 20, 6042-6047. [CrossRef] [PubMed]

16. Vázquez, A. $\alpha 9 \alpha 10$ acetylcholine receptors: Structure and functions. Neurotransmitter 2016, 3, e1298.

17. Xu, S.; Shao, X.; Yan, M.; Chi, C.; Lu, A.; Wang, C. Identification of Two Novel O2-Conotoxins from Conus generalis. Int. J. Pept. Res. Ther. 2015, 21, 81-89. [CrossRef]

18. Xu, S.; Zhang, T.; Kompella, S.N.; Yan, M.; Lu, A.; Wang, Y.; Shao, X.; Chi, C.; Adams, D.J.; Ding, J.; et al. Conotoxin $\alpha \mathrm{D}-\mathrm{GeXXA}$ utilizes a novel strategy to antagonize nicotinic acetylcholine receptors. Sci. Rep. 2015, 5, 14261. [CrossRef] [PubMed]

19. Luo, S.; Zhangsun, D.; Feng, J.; Wu, Y.; Zhu, X.; Hu, Y. Diversity of the O-superfamily conotoxins from Conus miles. J. Pept. Sci. 2007, 13, 44-53. [CrossRef] [PubMed] 
20. Luo, S.; Zhangsun, D.; Harvey, P.J.; Kaas, Q.; Wu, Y.; Zhu, X.; Hu, Y.; Li, X.; Tsetlin, V.I.; Christensen, S.; et al. Cloning, synthesis, and characterization of $\alpha \mathrm{O}$-conotoxin GeXIVA, a potent $\alpha 9 \alpha 10$ nicotinic acetylcholine receptor antagonist. Proc. Natl. Acad. Sci. USA 2015, 112, E4026-E4035. [CrossRef] [PubMed]

21. Lu, A.; Yang, L.; Xu, S.; Wang, C. Various conotoxin diversifications revealed by a venomic study of Conus flavidus. Mol. Cell. Proteom. 2014, 13, 105-118. [CrossRef] [PubMed]

22. Walker, C.S.; Jensen, S.; Ellison, M.; Matta, J.A.; Lee, W.Y.; Imperial, J.S.; Duclos, N.; Brockie, P.J.; Madsen, D.M.; Isaac, J.T.; et al. A novel Conus snail polypeptide causes excitotoxicity by blocking desensitization of AMPA receptors. Curr. Biol. 2009, 19, 900-908. [CrossRef] [PubMed]

23. Quinton, L.; Gilles, N.; De Pauw, E. TxXIIIA, an atypical homodimeric conotoxin found in the Conus textile venom. J. Proteom. 2009, 72, 219-226. [CrossRef] [PubMed]

24. Chen, L.; Durr, K.L.; Gouaux, E. X-ray structures of AMPA receptor-cone snail toxin complexes illuminate activation mechanism. Science 2014, 345, 1021-1026. [CrossRef] [PubMed]

25. Elgoyhen, A.B.; Johnson, D.S.; Boulter, J.; Vetter, D.E.; Heinemann, S. $\alpha 9$ : An acetylcholine receptor with novel pharmacological properties expressed in rat cochlear hair cells. Cell 1994, 79, 705-715. [CrossRef]

26. Elgoyhen, A.B.; Vetter, D.E.; Katz, E.; Rothlin, C.V.; Heinemann, S.F.; Boulter, J. $\alpha 10$ : A determinant of nicotinic cholinergic receptor function in mammalian vestibular and cochlear mechanosensory hair cells. Proc. Natl. Acad. Sci. USA 2001, 98, 3501-3506. [CrossRef] [PubMed]

27. Elgoyhen, A.B.; Katz, E.; Fuchs, P.A. The nicotinic receptor of cochlear hair cells: A possible pharmacotherapeutic target? Biochem. Pharmacol. 2009, 78, 712-719. [CrossRef] [PubMed]

28. Haberberger, R.V.; Bernardini, N.; Kress, M.; Hartmann, P.; Lips, K.S.; Kummer, W. Nicotinic acetylcholine receptor subtypes in nociceptive dorsal root ganglion neurons of the adult rat. Auton. Neurosci. 2004, 113, 32-42. [CrossRef] [PubMed]

29. Kurzen, H.; Berger, H.; Jager, C.; Hartschuh, W.; Naher, H.; Gratchev, A.; Goerdt, S.; Deichmann, M. Phenotypical and molecular profiling of the extraneuronal cholinergic system of the skin. J. Investig. Dermatol. 2004, 123, 937-949. [CrossRef] [PubMed]

30. Peng, H.; Ferris, R.L.; Matthews, T.; Hiel, H.; Lopez-Albaitero, A.; Lustig, L.R. Characterization of the human nicotinic acetylcholine receptor subunit $\alpha 9$ (CHRNA9) and $\alpha 10$ (CHRNA10) in lymphocytes. Life Sci. 2004, 76, 263-280. [CrossRef] [PubMed]

31. Kumar, P.; Meizel, S. Nicotinic acetylcholine receptor subunits and associated proteins in human sperm. J. Biol. Chem. 2005, 280, 25928-25935. [CrossRef] [PubMed]

32. Simard, A.R.; Gan, Y.; St-Pierre, S.; Kousari, A.; Patel, V.; Whiteaker, P.; Morley, B.J.; Lukas, R.J.; Shi, F.D. Differential modulation of EAE by $\alpha 9^{*}$ - and $\beta 2^{*}$-nicotinic acetylcholine receptors. Immunol. Cell Biol. 2013, 91, 195-200. [CrossRef] [PubMed]

33. Vincler, M.; Wittenauer, S.; Parker, R.; Ellison, M.; Olivera, B.M.; McIntosh, J.M. Molecular mechanism for analgesia involving specific antagonism of $\alpha 9 \alpha 10$ nicotinic acetylcholine receptors. Proc. Natl. Acad. Sci. USA 2006, 103, 17880-17884. [CrossRef] [PubMed]

34. Callaghan, B.; Haythornthwaite, A.; Berecki, G.; Clark, R.J.; Craik, D.J.; Adams, D.J. Analgesic $\alpha$-conotoxins Vc1.1 and Rg1A inhibit N-type calcium channels in rat sensory neurons via GABA receptor activation. J. Neurosci. 2008, 28, 10943-10951. [CrossRef] [PubMed]

35. Mohammadi, S.A.; Christie, M.J. Conotoxin interactions with $\alpha 9 \alpha 10$-nAChRs: Is the $\alpha 9 \alpha 10$-nicotinic acetylcholine receptor an important therapeutic target for pain management? Toxins (Basel) 2015, 7, 3916-3932. [CrossRef] [PubMed]

36. Vincler, M.; McIntosh, J.M. Targeting the $\alpha 9 \alpha 10$ nicotinic acetylcholine receptor to treat severe pain. Expert Opin. Ther. Targets 2007, 11, 891-897. [CrossRef] [PubMed]

37. McIntosh, J.M.; Absalom, N.; Chebib, M.; Elgoyhen, A.B.; Vincler, M. $\alpha 9$ nicotinic acetylcholine receptors and the treatment of pain. Biochem. Pharmacol. 2009, 78, 693-702. [CrossRef] [PubMed]

38. Pacini, A.; Micheli, L.; Maresca, M.; Branca, J.J.; McIntosh, J.M.; Ghelardini, C.; Di Cesare Mannelli, L. The $\alpha 9 \alpha 10$ nicotinic receptor antagonist $\alpha$-conotoxin RgIA prevents neuropathic pain induced by oxaliplatin treatment. Exp. Neurol. 2016, 282, 37-48. [CrossRef] [PubMed]

39. Adams, D.J.; Callaghan, B.; Berecki, G. Analgesic conotoxins: Block and G protein-coupled receptor modulation of N-type Cav2.2 calcium channels. Br. J. Pharmacol. 2012, 166, 486-500. [CrossRef] [PubMed] 
40. Lee, C.H.; Huang, C.S.; Chen, C.S.; Tu, S.H.; Wang, Y.J.; Chang, Y.J.; Tam, K.W.; Wei, P.L.; Cheng, T.C.; $\mathrm{Chu}$, J.S.; et al. Overexpression and activation of the $\alpha 9$-nicotinic receptor during tumorigenesis in human breast epithelial cells. J. Natl. Cancer Inst. 2010, 102, 1322-1335. [CrossRef] [PubMed]

41. Zhangsun, D.; Zhu, X.; Kaas, Q.; Wu, Y.; Craik, D.J.; McIntosh, J.M.; Luo, S. $\alpha$ O-Conotoxin GeXIVA disulfide bond isomers exhibit differential sensitivity for various nicotinic acetylcholine receptors but retain potency and selectivity for the human $\alpha 9 \alpha 10$ subtype. Neuropharmacology 2017. [CrossRef] [PubMed]

42. Morales-Perez, C.L.; Noviello, C.M.; Hibbs, R.E. X-ray structure of the human $\alpha 4 \beta 2$ nicotinic receptor. Nature 2016, 538, 411-415. [CrossRef] [PubMed]

43. Azam, L.; McIntosh, J.M. Molecular basis for the differential sensitivity of rat and human $\alpha 9 \alpha 10$ nAChRs to $\alpha$-conotoxin RgIA. J. Neurochem. 2012, 122, 1137-1144. [CrossRef] [PubMed]

44. Christensen, S.B.; Bandyopadhyay, P.K.; Olivera, B.M.; McIntosh, J.M. $\alpha$ S-conotoxin GVIIIB potently and selectively blocks $\alpha 9 \alpha 10$ nicotinic acetylcholine receptors. Biochem. Pharmacol. 2015, 96, 349-356. [CrossRef] [PubMed]

(C) 2017 by the authors. Licensee MDPI, Basel, Switzerland. This article is an open access article distributed under the terms and conditions of the Creative Commons Attribution (CC BY) license (http:/ / creativecommons.org/licenses/by/4.0/). 